\title{
$\begin{array}{lll}\text { N.0 } 78 \quad \text { Abril-Junho } & 1969\end{array}$ \\ Vol. XXXVIII - REVISTA DE HISTÓRIA - Ano XX \\ CONFERE N C I AS
}

\section{RELIGIÃO E HISTÓRIA $\left({ }^{*}\right)$.}

\section{JORGE BERTOLASO STELLA \\ da Socledade de Estudos Históricos.}

Nêste momento, cabe-me a honrosa tarefa de falar sôbre a religião e a história .

Confesso, não sei se haverá assunto mais amplo, mais atraente e ao mesmo tempo mais árduo do que êste.

Em vista da importância da matéria e limitado a êstes poucos minutos, sinto-me embaraçado em apresentar as vigas mestras da religião sobrepostas às vigas mestras da história . Direi entretanto algumas palavras que, quando nada, expressarão a minha boa vontade em colaborar num campo apreciável como êste.

Devendo, em seguida, o distinto Prof. Frei Luís-Bertrando Gorgulho, O. P. falar sôbre o tema história e religião, tenho receio de invadir o seu campo, porque religião e história são tão entrelaçadas que não sei como separá-las, assemelhando-se ao meu espírito às atraentes côres do arco-iris

Não é fóra de propósito afirmar que os dois têrmos unidos formam o tecido do homem no tempo e no espaço. Onde está a religião aí está a história, onde está a história, aí está a religião.

Ambas são irmãs gêmeas, a mais velha entretanto é a religião sem pretender contrariar o pensamento do Renan quando disse que sem história não pode existir a ciência da humanidade (1) .

Pena é que a religião do homem não tenha o seu arquivo completo e se perdesse no passado, lástima é ainda que a história do homem não tenha sido escrita e não possa ser reconstituída.

$O$ que sabemos do homem é quase nada em relação à sua longa e misteriosa existência.

Se tomarmos em conta a história da terra, aproximadamente dois mil milhões de anos, a história da vida sôbre a terra cêrca de

\footnotetext{
(*). - Conferência IIda pelo Rev. Jorge César Mota, na Sociedade de Estudos Históricos no dia 22 de novembro de 1968 (Nota da Redação).

(1). - Dujovne L.. La filosofia de la historia en la antiguidad y en la Edad Media, Cordoba, 1958, pg. 14.
} 
quinhentos milhões de anos e considerarmos os milênios do homem nêste mundo em relação à história, a sua história é como um primeiro minuto de um nôvo acontecer (2).

À semelhança do mundo exterior o homem é ainda um mistério. Não sabemos com certeza quando apareceu no cenário da vida, em que ponto do globo surgiu a despeito das várias hipóteses, que caminhos trilhou segundo a etnogonia. Talvez nunca chegaremos a decifrar as suas pegadas, que constituem as etapas da história.

2. - Duas teorias se defrontam, no campo da escola antropológica, que constituem o problema máximo da História das Religiões: a primeira sustenta que o monoteísmo se desenvolveu do politeísmo; a segunda que o monoteísmo é o princípio da evolução religiosa .

A teoria politeísta parte do princípio que o homem nasceu sem o sentimento religioso e portanto não tinha culto algum. Chegando êle a um certo grau de maior desenvolvimento divinisou certos objetos, considerados de alguma importância para êle, como por exemplo, uma árvore, uma pedra, um rio; atingindo um grau de mais alta cultura, divinisou o fogo, os astros e especialmente o sol; contemplando finalmente a harmonia do céu, chegou ao conceito de um Deus único. Assim o homem, no seu desenvolvimento religioso, percorreu as seguintes etapas: ateísmo, fetichismo, politeísmo e monoteísmo. A outra teoria afirma que o politeísmo é um fracionamento do monoteísmo primitivo e que o fetichismo dos baixos extratos da raça humana é o resíduo de noções religiosas mais altas e mais puras, recebidas dos antepassados.

O homem nasceu religioso.

A religiosidade é um fenômeno universal.

Quatreface escreveu:

"A idéia religiosa se encontra em todo o globo e em todos os sêres humanos" (3).

Este conceito traz à memória o largo lance de Plutarco:

\begin{abstract}
"Viajando poderás encontrar cidades sem muralhas, sem literaturas, sem reis e sem casas, sem riquezas e sem o uso de moedas, desprovidas de teatros e de ginásios. Mas uma cidade sem templos e sem deuses, que não pratique nem orações, nem juramentos, nem advinhações, nem sacrifícios para impetrar o bem e deprecar os males, ninguém jamais a viu, nem nunca a verá".
\end{abstract}

As raças humanas variam com o clima, mas a humanidade é uma só.

(¿). - Jasper K., Origen y Meta de la historia, Madrid, 1965, pg. 54.

(3) . - Marcozzi V., L'uomo nello spazio e nel tempo, Roma, 1953, pg. 113. 
Onde quer que exista um ser humano, aí, de uma forma ou de outra, encontra-se a religião.

Sendo a história o mundo da liberdade, decorre dai a variedade e portanto a comparação (4).

Não existe religião sem uma inicial afirmação da realidade do divino (5) .

Spinoza afirmava que os profetas de Israel não podiam realmente ter conhecido a Jeová, que a êles se revelou, se não tivessem tido, em si mesmos de alguma sorte, uma idéia do divino. E mais tarde Schelling acrescentou para que nascesse a religião devia haver uma consciência religiosa $(6)$.

3. - Há estudiosos que consideram o princípio da história o emprêgo da escritura; outros tomam o comêço da história a prática da agricultura; outros ainda afirmam ser o princípio da história as primeiras manifestações da metalúrgica (7).

A história pròpriamente começa com o homem.

"O sujeito da história é o homem. Não são as fôrças cegas da natureza, nem os principios universais da razão, nem a idéia absoluta, nem as fôrças produtivas, os agentes da história; o verdadeiro protagonista é o homem, as ações humanas", disse Bultmann (8).

Para alguns, já o dissemos, a história de um povo tem o seu início quando começa a usar a escritura. Daí "povos históricos" equivalem a "povos com escrita".

Como é bem de vêr, esta maneira de julgar coloca fóra da história quase a maior parte da humanidade e a razão disso é que inúmeros povos e tribos, que como ocupavam grandes territórios, eram considerados como sem história por falta da escrita.

Maringer (9) judiciosamente observa: colocar à parte, como "sem história", o período anterior à escrita, era um êrro, porque a história é tão antiga quanto a humanidade.

Precisamos considerar que não faltam documentações de valia para os tempos anteriores à escrita. E' claro que não são documentos escritos com ponteiro ou pena sôbre a pedra, metal ou papiro, etc., mas extraídos a custo de pico e de pá dos inúmeros arquivos da terra.

(4). - Peitazoni R., Religione e Società a Cura de Candini, pg. 108.

(5). - Nobile E., Pressupposti filosofici, pg. 61.

(6) . - Puglisi M., La preghiera, Torino, 1928, pg. 10 .

(7). - Dujovne L., La filosofia de la historia en la antiguidad $y$ en la Edad Media, Cordoba, 1958, pg. 10.

(8). - Massuh V., Sentido y fin de la historia, Buenos Aires, 1963, pg. 56-68.

(9) . - Maringer J., Le religioni dell'età de la pietra in Europa, Torino, 1960, pg. 2. 
Esses documentos são constituídos de armas, utensílios de pedra, de osso ou de metal, das urnas e cerâmicas, sepulturas, resíduos, fortificações e restos mais antigos do passado humano sepultado na terra.

Este material atesta a vida superior dos nossos antepassados. As sepulturas, por exemplo, falam do culto dos mortos, as fortificações lembram a defesa contra $o$ invasor, os vasos e a cerâmica, com a sua ornamentação, constatam os costumes e o gôsto de nossos avós.

Nessas linhas, creio, não seria fora de propósito se afirmarmos que a história é a caverna, a história é o fogo,

"a história, como disse Benedito Croce, é a natureza" (10).

4. - A história não é narrativa de acontecimentos mortos.

$\mathrm{Na}$ opinião de Cassirer,

"a história é um órgão de conhecimento de nós mesmos, um instrumento indispensável para construir o nosso universo humano" (11):

A história com as suas múltiplas e variadas manifestações oferece-nos uma noção plena do humano.

Max Müller escreve:

"A verdadeira história é a história da religião: os maravilhosos caminhos que seguiram as diferentes famílias da raça humana para avançar até um conhecimento mais verdadeiro e até um mais profundo de Deus.

Este é o fundamento que sobressai em tôda a história profana: é a luz, é a alma, é a vida da história e sem ela tồda a história seria realmente profana" (12).

Notável, dissemos, é a união entre ambas. A religião nasceu com o homem e com a religião nasceu a história. Uma não existe sem a outra .

E' de Rèville êste conceito:

"A história das religiões é a história da humanidade, a história da alma humana desde a sua origem, no trabalho incessante das suas aspirações, as mais sagradas e das suas necessidades, as mais profun-

\footnotetext{
(10). - Dujovne L., La filosofia de la historia en la antiguidad y en la Edad Media, Cordoba, 1958, pg. 9.

(11). - Dujovne L.. La filosofia de la historia en la antiguidad y en la Eaad Media, Cordoba, 1958, pg. 15:

(12) ... - Wach J., El estudio comparado de las religiones, Buenos Aires, 1967, pg. 57.
} 
dạs, com variedade infinita das instituições, das crenças e práticas pelas quais através do tempo e do espaço, ela tem procurado satisfazê-las" (13).

No passado o mundo religioso era a Bíblia, especialmente para judeus e cristãos; os Vedas era o mundo religioso para os hindus, o Rig-Veda, a mais antiga Bíblia do homem; o Avesta para os persas; o Corão para o islamismo. Hoje o mundo religioso é a história (14).

A história do pensamento começou com a religião (15).

Nessa mesma direção, expressou-se Altheim:

"Poucas cousas haverá no domínio humano que não hajam brotado da raiz religiosa ou não hajam sido plasmadas pelos impulsos religiosos (16).

Tôda cultura quer escrita, quer tradição oral, que vem dos primórdios da humanidade tem um fundo religioso. Em tôda a parte, os documentos mais antigos são documentos religiosos, na opinião de Max Müller .

"A terra que habitamos, no sentir de Herder, deve os germes de tôda a alta cultura a uma tradição escrita ou oral" (17).

5. - O primeiro arquivo da religião é o homem mesmo.

"O estudo da religião é o estudo de uma pessoa". "A fé é a qualidade da vida do homem. Tôdas as religiōes são novas cada manhã, pois as religiōes não existem em algum lugar do céu, elaboradas, terminadas, estáticas; elas existem nos corações dos homens" (18).

A experiência religiosa é constitutiva da natureza do homem:

"A nossa comum natureza humana contém uma permanente possibilidade de religião", disse Maret (19) e em outra parte prossegue êle: "o sentido religioso do homem é uma constante e universal característica da sua vida mental".

(13) . - Rèville J., Les phases successives de la histoire des religions, Paris, 1909, pg. 9 .

(14). - Pettazzoni R., Letture religiose: hebraismo, cristianismo, pg. 3.

(15) . - Puint C., Saggi di storia delle religioni, Flrenze, 1882, pg. 291.

(16). - Altheim F., El Dio invicto, Buenos Aires, 1966, pg. 5.

(17) . - Müler M., Origen y desarrolo de la religion, Madrid, pg. 16 .

(18). - Eliade M., y Kitagawa J. M., Metodologia de la historia de las religiones, Buenos Aires, 1967, pg. 57 (6).

(1€) . - Eliade M. Y. Kitagawa J. M., Metodologia de la historia de las religiones, Buenos Alres, 1967, pg. 110-111. 
A experiência religiosa corre sôbre os trilsos das emoções, a experiência é o domínio da história (20).

6. - Deparamos com a história da religião no fogo cujos traços encontram-se no período chelense, há 100.000 anos mais ou menos.

Como é sabido, o fogo natural vem do céu e da terra. As florestas incendiavam-se feridas pelos raios. Nas terras limítrofes dos vulcões, as massas de lavas incandescentes, lançadas das crateras, continuavam a arder durante muito tempo.

Em tôdas as terras notavam-se emanações de gazes fàcilmente inflamáveis.

Dessas fontes ígneas o homem podia ocasionalmente ter tirado o fogo. E' possível que a adoração e o culto ao fogo tivessem sua origem destas fontes ígneas.

Era o fogo considerado tão precioso que o supunham guardado no céu pelos deuses, sua sede natural, de onde vinha, às vêzes terrível, em forma de raio. Daí o célebre mito de Prometeu. Porém o homem chegou a descobrir como acender o fogo e obteve a sua defesa plena.

A história do fogo é a história da civilização humana.

Por meio do fogo o homem expulsou as feras das cavernas, tornando-as sua habitação e seu santuário.

O fogo foi auxílio na caça, coeficiente na agricultura e fundamento da cozinha.

Por tôdas as razões êle foi considerado sagrado e o símbolo da divindade.

A religião dos persas é chamada a religião do fógo. Êles são denominados os "adoradores do fogo".

O sentimento religioso que aflorou no homem e se foi desenvolvendo consoante a sua cultura, arquivado pela viga da tradição, foi tomando forma mais clara, quando pôde ter sua morada na caverna.

7. - A história da religião se encontra nas cavernas. As cavernas são consideradas verdadeiros arquivos nos quais são conservados os preciosos documentos: da vida humana e da vida animal.

Com o exame metódico dos restos dos animais, pode-se reconstruir, diz Caselli (21), o mundo pré-histórico e mostrar que as cavernas serviram de habitação humana, de necrópole e santuário, da época quaternária.

(20). - Shotowell T. J., A interpretação da história, 1967, Rio de Janeiro, pg. 9. (21) . - Caselli G., Speleologia. 
Nos tempos históricos encontramos muitas cavernas sepulcrais. Entre outras, citamos a caverna de Machpela, onde Abrão sepultou sua espôsa Sara [Gênesis, 23:19].

Quer nos tempos pré-históricos, quer nos históricos, é difícil deparar-se com uma caverna que não tenha uma tradição religiosa. Há vários nomes que as caracterizam: Gruta do Diabo, do Dragão, das Fadas, do Inferno, etc:

$E^{\prime}$ interessante observar que os persas celebram nas grutas o culto secreto de Mitra.

Destacamos alguns exemplos que mostram a importância das cavernas. A caverna de Lascaux, descoberta em 1940, é um dos mais preciosos santuários. Nela se encontram pinturas de animais considerados totens. Não se encontra nela traços da moradia do homem e é tida, acima de tudo, como um santuário.

Não menos célebre é a Caverna de Altamira no norte da Espanha. Foi descoberta por Marcelino de Santuola, em 1868.

A história dos achados desta caverna é um romance. A galeria de pinturas foi o principal santuário. Pela sua importância, é comparada à Capela Sixtina. Citamos ainda a caverna de Drachenloch, chamada caverna ritual. Os crâneos dos grandes ursos, acumulados como "depósitos altares" revelam a antiga prática da magia da caça .

8. - Razões várias aconselhavam a sepultar o morto na caverna. Não sòmente livravam-no de ser devorado pelas feras, mas era considerado "um cadáver vivo" permanente no ambiente da família.

O cadáver era sepultado no chão, "na posição de quem dorme" ou de costa, outras vêzes, agachado.

A maneira como o sepultavam, conforme a posição, os utensílios junto do morto, suas armas e tudo quanto lhe pertencia em vida, mostravam que acreditavam numa outra existência, na qual o morto precisava de tudo quanto the foi útil neste mundo. Para êles a morte não era o fim.

Não raras vêzes, colocavam o cadáver entre as cinzas quentes, não com o fim de cremá-lo, mas para aquecer o corpo morto.

Outras vêzes o cadáver era sepultado com grossa camada de ocre. A côr vermelha do ocre lembrava o sangue e era usado para proporcionar ao cadáver pálido, o matiz da vida.

Os primitivos acreditavam que os mortos eram capazes tanto de boas como de más ações e atribuiam-lhe mais poderes do que aos próprios vivos. Ao prestarem culto aos mortos não sòmente o faziam com o fim de honrá-los, mas também de pedir-lhes, proteção e auxílio para a tribo. 
E' de tal importância o culto aos mortos que alguns estudiosos afirmam ter dado origem à religião.

9. - No período relativamente próximo a nós, solutrense $(20.000$ a. C. $)$ e magdalense $(15.000$ a 10.000 a. C. $)$, processava-se o culto ao crâneo humano. O crâneo era usado como amuleto.

Com êste culto acreditavam os antigos que os mortos ainda estavam presentes entre os vivos. Ao beberem por seu intermédio como uma taça, esperavam receber as energias do espírito do falecido. Uma descoberta em Pompéia, 1875, constata um crâneo engastado em metais preciosos com a seguinte inscrição em grego:

$$
\text { "Bebe e viverás muitos anos" (22). }
$$

Ainda uma palavra sôbre a maneira de sepultar os mortos. Não eram sòmente depositados na gruta. Erguiam, às vêzes, enormes edifícios, chamados monumentos megalíticos, formados com grandes blocos de pedra, cuja entrada se parecia com a de uma caverna.

Esses edifícios recebia mo nome de dólmen (palavra céltica): $d o ́ l=$ tábua, $m e n=$ pedra, mesa de pedra $)$. Em alguns casos, ao lado do dólmen, havia uma abertura talvez para a passagem do espírito, a fim de introduzir o alimento para o cadáver.

Em certos casos, encontravam-se nos dólmen vestígios de banquetes funerários.

Análogo aos dólmens depara-se também com o menhir (têrmo igualmente céltico, $m e n=$ pedra, hir $=$ comprida, mesa comprida $)$. Há estudiosos que afirmam ser um símbolo religioso ou um ídolo.

Quanto ao Egito, para ser breve, cito as palavras de Michelet: Egito".

E Murmura comenta:

"Isto revela um outro caráter da religião egípcia onde pela primeira vez se exprime o pensamento dó além e se através do mistério das Pirâmides a certeza da vida na morte" (23).

10. - O "bastão de comando", tem sido interpretado sob vários aspectos pelos estudiosos. Seu uso sagrado era "bastão mágico". Esse símbolo lembra a vara de Moisés [Ex. 4:20].

11. - Havia igualmente, nesses tempos recuados, o culto às águas. As fontes que brotavam das fendas das montanhhas tinham seus adoradores.

(22). - Maringer J., Os Deuses do homem pré-histótico, 1956, pg. 77-79.

(23). - Murmura E., L'Egitto $e$ i Presocratici, alle Fonti delli Religionl, anno II N. 3-4, p. 43 , Roma, 1924. 
12. - Nas paredes das grutas e dos monumentos megalíticos, encontravam-se um machado com uma figura feminina. $\mathrm{O}$ culto ao machado é de época antiquíssima. O ídolo feminino aparece na sepultura como guardador do recinto mortuário .

Tem-se encontrado miniaturas de machados neolíticos que, com certeza, eram amuletos ou objetos votivos.

$\mathrm{Na}$ Europa ocidental neolítica, observa Maringer (24), o machado era o símbolo do céu ou do raio lançado pelos deuses.

13. - A dança e a pintura da parede Coguel em que bailam nove mulheres ao redor de um homem nú, não é única em seu gênero, pois há outras representações cujas personagens dançam com máscaras de animais.

"O selvagem não pratica sua religião senão pela dança".

Existe certo paralelismo etnográfico com os atuais disfarces animais e com a dança de máscara que tem grande importância no cerimonial religioso de certos povos primitivos.

14. - Os pesquisadores não se prendem sòmente às grandes $\mathrm{e}$ históricas religiões da humanidade, mas também às religiões do vulgo, por alguns desprezadas.

Tôda a crença, tôda a idéia religiosa, por ridícula ou absurda que pareça, possui a sua história, a qual revela que, admitidos certos modos de conceber e dado o ambiente em que aquelas idéias se formaram e evolveram, tem a sua razão de ser, a sua necessidade de existir.

Luciano e outros escritores da Antigüidade pagã não teriam talvez ridicularizado os seus deuses e o culto a êles atribuído se tivessem conhecido a sua história (25).

Os códigos sagrados dos diversos povos representam a religião no seu grau de desenvolvimento e, como é natural, constituem o registro dos grandes grupos religiosos da humanidade.

Mas os fundamentos primeiros dêsses códigos são justamente essas modestas religiões populares.

O têrmo religião, no seu significado mais amplo, denota um liame da dependência que prende o homem a um ou mais poderes superiores aos quais se sente ligado e a quem tributa atos de culto individuais ou coletivos.

Nesta definição são compreendidos todos os elementos essenciais que constituem a religião no seu mais amplo sentido, isto é: 19). - a crença nos poderes superiores, que, segundo os vários

(24) . - Maringer J., Os Deuses do homem pré-histórico, 1956, pg. 212.

(25). - Puini C., Saggi di Storia delle religioni, Firenze, 1882, pg. 12, 13. 
graus de religião, pode ser um ou mais, pessoais ou impessoais; $2^{\circ}$ ). - o vínculo de dependência (de qualquer gênero e de qualquer sentimento provocado) que liga o homem aos poderes superiores; $3^{9}$ ) . - o modo prático com que êste liame se explica (qualquer que seja o gênero e a elevação dos atos) e que constitui o conjunto de ritos e práticas, mediante os quais a religião se concretiza nos agrupamentos humanos e exprime os seus sentimentos e as suas necessidades.

A palavra religião, comum a tôdas as línguas da Europa Ocidental é uma forma românica da palavra latina religio .

O tềrmo religio deriva de re-legere ou re-ligere (recolher, chamar à mente, refletir com certa intensidade de pensamnto). Porém vulgarmente, pelo menos de Latâncio a esta parte, ela se considera derivada de re-ligare (ligar, unir) e tal etimologia, embora filològicamente não seja exata, tem no entanto a vantagem de exprimir melhor o significado verdadeiro e atual da palavra (26) .

Religio é palavra latina, como foi dito, conservada nas línguas derivadas do latim e introduzida, como palavra importada, em quase tôdas as línguas da Europa Ocidental, porém em vão procurar-se-ia em outro lugar a exata tradução. Nem o grego, nem o hebraico, nem as línguas célticas, nem as indianas, nem as germânicas, têm o recurso para traduzir o têrmo religio dos latinos. E o que se diz do têrmo genérico e fundamental deve-se dizer também dos vocábulos que indicam algumas importantes categorias de fatos religiosos .

"A lingüística indo-européia, diz Meillet, não pode trazer se não poucas sólidas testemunhas ao estudo comparado da mitologia e das religiões. Em campo algum o dicionário é mais divergente que nos têrmos relativos à religiăo. Nem o sacrifício, nem rito algum são designados com palavras comuns à mais línguas" (27).

\section{* \\ RELIGIOES E SUAS DIVISÕES.}

As religiões estudadas sob o aspecto histórico-crítico são suceptíveis de várias subdivisões conforme o ponto de vista que são examinadas:

1. - Se se considera o objeto da crença religiosa ou sejam os sêres superiores aos quais se dirige a homenagem dos homens, tem-se a tríplice divisão em religiões animísticas, politeísticas e monoteísticas;

(26) . - Grandmaison L., Lo studio delle religioni in Storia delle religione di C. C. Martindade, Firenze, 1913, vol. I, p. 3.

(27) . - Graneris, Introduzione Generale alla scienza della Religioni, Torino, 1952, 1952 , p. 70, 71 . 
2. - Se se considera o estado social dos grupos humanos que aderem às várias religiões, tem-se uma nova tripartição em religiões tribais, nacionais e universais;

3. - Se se considera finalmente o desenvolvimento histórico-moral dos grupos humanos, tem-se uma terceira divisão das religiões em duas grandes subdivisões: religiões naturais e religiões históricas (28).

As religiões podem ser estudadas também sob o aspecto: teológico, próprio de cada uma; sob o ponto de vista filosófico, que se procura as afinidades da razão e da fé; as condições humanas da gênesis e do desenvolvimento da religião e se julga a respeito do grau de verdade de falsidade de uma religião: sob o ponto de vista histórico, em que prescindindo de tôda questão de princípio, estudam-se os fatos documentados e momentos oferecidos pelas religiões, coordenam-se e se expõem, oferecendo assim materiais para uma síntese ulterior (29).

Ao Terceiro Congresso de História das Religiões, Oxford, 1908, Goblet D'Aviella propôs uma terminologia mais simples para designar estas três ramificações da ciência das religiões:

19). - A lierografia tem por objeto descrever tôdas as religiōes conhecidas e traçar o desenvolvimento respectivo;

2\%). - A hierologia procura estabelecer as relações de concomitância e de sucessão entre os fenômenos religiosos, em outras palavras, formular as leis da evolução religiosa;

$3^{\circ}$ ). - A hierosofia tem por fim formular as consequiências lógicas que dão, no domínio religioso, a concepção clara de nossas relações com Deus e o Universo (30).

15. - Sob o aspecto tipológico, às religiões do mundo se dividem em dois grandes grupos: religiões nacionais e religiões super-nacionais.

Dentre as religióes super-nacionais as três maiores são: cristianismo, budismo e islamismo e possuem as seguintes caracteríticas:

19). - Elas remontam a um fundador, respectivamente a Cristo, a Buda e a Maomé:

29). - Possuem o ideal soteriológico, tratam da salvação do homem;

(28). - Turchi N., Le religioni misteriosofiche del Mondo antico, Roma, 1923, p. 5,6 .

(29). - Turchi N., Storia della religioni, Torino, 1922, p. 2, vol. I.

(30) . - Goblet D'Aviella, Groyances, Rites, Instituitions, Tomo II, p. 192, 193. Paris, 1911, Graner1, Introduzione alla Scienza delle Religioni, 1952, p. 63. 64. 
39). - Exercem o proselitismo, tendem a conquistar novos aderentes;

49). - Possuem livros sagrados de valor canônico: o cristianismo tem a Bíblia, o budismo o "pequeno veículo" hinayana, compreendendo o Tipitaka, "o grande veículo" mahayana, o islamismo possui o Corão.

O caráter fundamental das religiões nacionais consiste no fato de uma religião limitar-se a uma determinada nação. Estas religiões não têm tendência expansionista, elas visam o bem do Estado.

As religiões nacionais, em regra, são religiões antigas, como, entre outras, a grega, a romana, a egípcia, etc. As religiões nacionais vivas são o confucionismo e o shintoísmo no Japão.

Tôda a tipologia porém está sujeita à exceção.

Também no campo das . religiões encontram-ṣe algumas formações históricas que não se enquadram nas duas grandes classes de religióes nacionais e super nacionais: a religião judaica, com o seu monoteísmo e Velho Testamento, revela notável afinidade com as religiões super nacionais. Entretanto, ela não sòmente nunca transpõe os limites da nação (alguns casos isolados de expansão na sua história proveniente de razões políticas e não por tendência de proselitismo religioso), mas antes sempre revela um caráter nacionalístico. Falta-lhe além disso, a preocupação escatológica (isto é, as crenças referentes à sorte da alma depois da morte e a sanção ultra-terrena na vida individual), enquanto tais preocupações são próprias a tôdas as religiões soteriológicas.

Há um grupo à parte de formações religiosas, constituído pelas religiões chamadas misteriosóficas, de Dionísio, órficas, de Eleusis, etc.

Estas religiões possuem elementos arcaicos e têm certas analogias com as religiões dos povos primitivos, que possuiam o rhombo, a máscara e a tatuagem.

Como a família é anterior ao Estado, os mistérios são anteriores à formação das nações e daí as religiões mistéricas derivarem de uma sociedade pré-nacional e por essa forma revelam as suas afinidades com as religiões super-nacionais.

Os historiadores apresentam várias escolas que se propõem a explicar a origem da religião e o seu desenvolvimento: escola filológica, também chamada naturalística e mitológica, escola antropológica, denominada também etnológica, a soociológica e a escola histórica-cultural, etc.

1. - A escola filológica foi designada com êsse nome dado o método de pesquisas principalmente filológicas. 
O material submetido ao exame mirava as religiões indo-européias, de modo especial a indiana e a irânica. A documentação foi baseada nas fontes exclusivamente literarías.

$\mathrm{O}$ iniciador da escola foi Alberto Kuhn, porém o fundador foi Max Müller .

Uma plêiade de estudiosos colaborou nêsse campo, e entre outros nomes citamos Eugênio Burnouf, H. Mayer, Bréal, Faust de Colange, A. Pictet, Regnaud.

Alguns benefícios trouxe esta escola. A pesquisa filológica teve o mérito de por em evidência o parentesco entre o sêr supremo dos indo-europeus: Dyaus Pitar sânscrito, Zeus pater grego, Júpiter latino, Perum russo, Donar Thor teutônico, Tanaras, Taranos céltico.

Se por um lado não se pode aceitar mais as teorias de Max Müller, segundo as quais os deuses védicos são transfigurações míticas de fatos naturais, por outro lado, diz Tucci (31), não se pode negar que grande parte da mitografia védica seja de caráter naturístico.

Seja-me permitido nessa altura, uma palavra sôbre o mito, a mais antiga narrativa histórica-milenária pois é tal a sua importância que, alguns estudiosos asseveram ter sido a forma originária de tôdas as religiōes.

O mito é "história verdadeira" e não "história falsa". História verdadeira pelo seu conteúdo, narração de fatos reais sucedidos, a começar pelos das origens: origem do mundo e da humanidade, origem da vida e da morte, origem das espécies animais e vegetais, origem da caça e da agricultura, origem do fogo, origem do culto, origem dos ritos iniciados, origem das sociedades samanísticas e dos seus poderes terapêuticos: acontecimentos longínqüos no tempo, dos quais teve princípio e fundamento a vida presente, dos quais procede a estrutura atual da sociedade. "O mito é história verdadeira porque é história sagrada", afirma Pettazzoni (32).

O mito é a história sagrada da tribo.

O mito não é uma história de fantasia, separada de algum fato, segundo Bessant (33). O mito é mais verdadeiro do que a história, porque a história sòmente dá a narrativa da sombra, enquanto que o mito dá a história da substância que projeta aquela sombra.

2. - A escola antropológica teve como alvo os povos chamados "primitivos".

Os estudiosos que seguiram êsse rumo eram, em regra, cultores das ciências naturais, embebidos das teorias de Darwinn.

(31). - Tucci G., Indutsmo: La Civiltà dell'oriente, pg. 569 .

(32) . - Pettazzoni R., Miti e Legende, Torıno, 1948, X, Religioni e Società, Bologna, 1966, pg. 9-10. Puini C., Storia dell religioni, Firenze, 1882, pg. 105.

(33). - Yanni U., Y Valori cristiani e la cultura moderna - Brescia 1934, pg. 60. 
Largo é o estudo histórico desta escola.

a). - No que tange ao animismo, o precursor foi o abade Bergier, 1767. Ele desenvolveu a idéia que tanto o fetichismo como a idolatria surgiram da mentalidade infantil que enche os objetos da natureza de gênios ou espíritos e assim os vivifica e os humaniza. $\mathrm{E}^{\prime}$ de notar que não deduziu desta a única fonte da religião.

Embora devêssemos citar longa lista de competentes, como J. Lubok, H. Spenser, o fundador pròpriamente da escola antropológica foi Edward Burnett Tylor, etnólogo de fama e evolucionista convicto.

Ele afirma que no período mais baix da religiosidade humana (correspondendo ao estado ou período da cultura inferior), encontra-se uma forma de religião, que êle, com um nome feliz chamou animismo, a qual consiste, da parte do selvagem, em animar mediante espíritos ou objetos reais ou imaginários com os quais a sua mortal fantasia vem encontrar-se e os adora.

Ele pensou assim encontrar no animismo as primeiras raízes da religião. Com largas e longas etapas procura justificar a sua teoria.

b). - Nesta mesma escola, apareceu outra teoria contra o animismo clássico, a qual, concebendo o desenvolvimento geral da religião de modo absolutamente diverso, punha o monoteísmo não no fim, mas no comêço da evolução religiosa. Essa foi a teoria de Andrew Lang, discípulo de Tylor, o qual abandonando as teorias do mestre, afirmou que não foi o animismo a primeira forma da religiosidade humana, mas um rudimentar monoteísmo (pré-animismo). Fundado sôbre a crença de um Sêr Supremo, compreendido como Pai Universal e como Criador.

As suas teorias foram combatidas; teve porém um defensor: o Padre Schmidt.

c). - Segundo os cânones estabelecidos pelos historiadores, o totemismo é sobretudo um liame, uma espécie de aliança entre um grupo de homens e uma espécie de animais ou vegetais.

Dada a sua dependência, o homem tem uma grande veneração pelo seu totem.

J. G. Frazer sistematizou o totemismo e apresentou largo material sôbre o assunto.

Ele nega que o totemismo seja uma religião.

"O totemismo, diz êle, não é religião de forma alguma; os totens não recebem culto, não são em sentido algum divindades; não são propiciados com oraçõeōs e sacrifícios. Falar em culto de totem, como alguns autores fazem, significa nada entender dos fatos" (34).

(34). - Frazer J. G., Totemism and Exagamy, IV., pg. 27. 
d). - J. H. King, 1892, foi o primeiro a sustentar que em vez do animismo deve-se por a magia como início do desenvolvimento religioso. Ele é o representante clássico da teoria pré-animista da magia.

Frazer é de opinião que a magia é a fase precedente da religião. Notadas algumas variedades, há uma longa lista de estudiosos que seguem essa teoria e entre êles Marett, Glodd, Hewitt, Artland, Mauss, Hubert, Durkheim.

3. - A escola sociológica tem à sua frente Durkheim. O campo do seu estudo é amplo como o mundo e a história. Abrange os povos cultos, mas especialmente os "primitivos".

Ela parte do princípio que a sociedade é a criadora de tôdas as grandes instituições sociais: o direito, a moral, a ciência. A religião é uma divinização da própria sociedade.

Durkheim põe o totemismo como origem da religião. Entretanto critica-se que: 19 ) . - o totemismo não é primitivo, nem universal; $2^{\circ}$ ) . - não se pode colocar no mesmo nível cultural tôdas as populações australianas, como fêz Durkheim, ao contrário, os exemplos apresentados por êle, com relação aos primitivos, são escolhidos dentre as populações que a etnologia demonstrou serem os menos primitivos.

4. - A escola histórico-cultural pode também ser chamada ciclo cultural etnográfico ou antrologia moderna.

Os historiadores a denominam escola alemã, sendo as outras uma francésa (a sociológica) e duas inglêsas.

O campo de estudo é vasto como a história e como a cultura.

A reação ao evolucionismo foi iniciada pelos etnólogos dos vários países. Citamos Quatreface, 1864, Ratel 1886, Pigorini e outros.

O movimento histórico na etnologia foi iniciado por Graebner, Akermann, Foy e de modo muito especial pelo Padre Schmidt. Schmidt, fundador e diretor da revista Anthropos, etnólogo de fama, lingüista de valor, prosseguiu nas pesquisas de Lang, defendendo a tese que os povos mais primitivos conservam a idéia de um Sêr Supremo, um culto simples e puro a êle dirigido, uma ética bastante elevada e colocada em estreita relação com a religião. Este estado religioso se aproxima à revelação primitiva. tudiosos.

O ponto de vista do Padre Schmidt é combatido por muitos es-

16. - A escatologia trata das últimas cousas, da relação entre a história e a eternidade. sureição.

O fim da história não é a destruiçã́o e a morte, mas vida e res- 
A "escatologia" cita Wach (35), é um modo simbólico de expressar a realidade dos propósitos de Deus na história.

Cristo, a figura central da história do mundo, veio cumprir uma missão escatológica na terra, assinalar que a promessa da redenção está ligada ao fim da história.

Jesus veio. $\mathrm{O}$ fato escatológico do reino começou no momento da sua encarnação e culminará no futuro com a segunda vinda, no fim dos tempos.

17. - "O homem é a sua história. O seu tecido é a sua própria existência" (36). Ele é a história, dissemos.

A história de morte é a história da religião, como é a história do nascimento, do renascimento, da transmigração da alma, da renovação moral.

A história do homem não termina com a sua morte. A morte é uma porta.

A morte é um nascimento num mundo desconhecido (37).

A morte é mais do que o fim, é o princípio (38).

Religião é consciência de Deus no homem e a morte não destrói essa consciência.

O homem sabe que depois da morte continua a viver. Ele procura descortinar algo com respeito ao além.

O livro Tibetano dos Mortos, o Livro dos Mortos dos Egípcios, a Bíblia e tantos outros, a filosofia da transmigração da alma, etc., oferecem campo vasto para o historiador .

Em se tratando de Jesus, Ele falou muito pouco a respeito da vida futura. Porém algumas das suas idéias são suficientes para tranquilizar e orientar nesse mundo escuro. Entre outros passos são sobremaneira interesantes os seguintes: "Pai, em tuas mãos entrego o meu espírito". "Eu vivo e vós vivereis" [João, 14:19]; "Na casa de meu Pai há muitas moradas" [João, 14:2].

18. - Como a árvore milenária nasceu pequena, seus ramos quebrados, muitas vêzes brotaram, seu tronco sacudido pelas tempestades abalaram raízes, abrindo fendas na terra pelas quais mais fundas penetraram, tirando a seiva, assim a religião que surgiu pequena, multiplicou-se em vários ramos, substituídos ou modificados, sacudida pelas guerras, perseguição e incompreensão, suas raízes se projetaram mais fundas nos corações humanos a fim de colher a vida em contacto com Deus.

(35) . - Wach J., El estudio comparado de las religiones, Buenos A1res, 1962, pg. 174.

(36). - Massuh V., Sentido e fin de la historia, Buenos Aires, 1963, pg. 55.

(37). - Lemaitre S., Le Mystere de la mort dans le religions d'Asie, Paris, 1963, pg. 53.

(38) . - Tucc1 G., Libro dei Morti dei Tibetani, pg. 10, 47. 
Talvez por isso Heiler, tivesse declarado

\author{
"que a impressão que transmite a história das religiões é de uma \\ maravilhosa riqueza de religiões" (39).
}

Pois bem, se eu tivesse de escolher uma religião como paradígma histórico-religiosa, apesar de várias propostas pelos historiadores, como por exemplo a religião grega, considerada

\footnotetext{
"uma das maiores idéias religiosas da humanidade", como "idéia religiosa do povo europeu" (40).
}

eu escolheria a religião egípcia e a de Cristo. Aquela a mais recuada, em que há muito da pré-história, da proto-história e da luz atual da história.

Os egípcios ocupam um lugar único na história da humanidade. Possuem os mais antigos documentos autênticos do mundo.

Nenhuma religião até agora durou tão longo tempo, no sentir de Cenci (41). Dada a sua duração, sua influência se fez sentir sôbre as outras religiões do Oriente, sôbre a antiguidade clássica.

A religião egípcia ocupou um lugar de grande importância na história da humanidade .

E esta, a religião de Cristo, que sendo uma das mais recentes, é ao mesmo tempo, a mais antiga do mundo, porque é a religião do amor.

Ele, abrindo as dobras secretas do delicado órgão, o coração, descobriu na criança, na mulher e no escravo, aquilo que as filosofias do seu tempo tentavam negar, a alma, a partícula divina no ser humano, a ponte que une a criatura a Deus.

19. - Há dois modos de resolver o problema da relação entre religião e cultura e consiste em anular a religião na cultura ou a cultura na religião. O primeiro é daqueles que consideram a religião superada pela ciência, pelo progresso. O segundo é dos crentes integrais, para quem a fé é que tem valor e cultura tem valor quando concorda com a fé, subordinada a ela.

Pettazzoni (42) afirma haver um terceiro modo de resolver o problema entre religião e cultura e consiste no modo histórico, o conhecimento da religião nas suas formas históricas concretas, em outras palavras, a história da religião.

(39). - Ellade e Katagawa, Metodologia de la historia de las religiones, pg. 172.

(40). - Pettazzonl R., Religione e società, Bologna, 1963, pg. 104, 105.

(41). - Cencl, Storia delle religioni, pg. 37 .

(42). - Pettazzoni R., Religione e società a cura di M. Gandini, Bologna, 1966, pg. 169-172. 
Religiões é um aspecto, uma forma da civilização a par de outras como o pensamento especulativo, estrutura social, vida econômica e política. Estas formas da religião não são isoladas, mas entrelaçam-se.

Não se pode conhecer a história de um povo se não se conhece a sua história, a sua arte, e sua poesia, a sua concepção do mundo. Por outro lado não se pode conhecer a vida de um povo, a sua civilização, a sua história, se não se conhece a sua religião.

A religião tem a tendência de enrijecer-se no dogmatismo e no formalismo exterior, de modo a apagar a chama da fé. Esta tendência se encontra especialmente nos extratos culturalmente humildes. Compete, nesse caso, a cultura reagir e enriquecer a religião empobrecida, livrando-a das escórias e reconduzí-la às fontes vivas da experiência interior .

Acontece, às vêzes, que a religião se avilta e exgotada, falsificada, esconde interêsse profano. E' justo que a cultura surja para resgatar a religião dessa servidão a fim de restaurá-la ao seu verdadeiro espírito.

Religião e cultura são heterogênias, mas não contraditórias. Elas se harmonizam quando se encontram num plano ideal em que a religião é vida interior e cultura é consciência histórica-religiosa.

A religião pois influenciou na história, revelou-se na atração da arte, frutificou como irmã gêmea na filosofia (43), na lingüística, floresceu na literatura, enriquecendo-a sobremaneira. Se infelizmente há fatos sangrentos com perseguições, em nome de Deus, há também páginas que mostram, como disse Renan, que a religião é amor, amor ao próximo, amor que amplia o conhecimento, "amor que é a primeira semente da inteligência", segundo o Rig-Veda (44), amor enfim que se revelou exuberante na história piedosa dos hospitais, na história da beneficência .

Não é só.

\footnotetext{
"O amor é a energia fundamental que move o universo. $O$ amor, afirma Teilhard, é energia físico-moral de personalização onde se reduzem finalmente tôdas as atividades manifestadas pelo esfôrço do Universo. O amor constrói fisicamente o Universo. O amor é a forma superior e o princípio totalizador da energia humana" (45).

"L'amore che move il sole e l'altre stelle" (46).
}

Se o aforismo de Bacon é válido, como eu penso:

(43). - Toymbee A., A religiáo e a histórta, Rio, pg. 223, 224.

(44) . - Somigliana A., Monismo indiano e Monismo grego nei frammenti di Eraclito, Padova, 1961, pg. 97.

(45) . - Detrez, A história $e$ o universo segundo Teilhard de Chardin, Paz e Terra, $29-$ pg. 33-34.

(46) . - Dante, Divina Comédia, Paradiso, XXXuI, 145. 
"Religio precipuum humanae societatis vinculum", a religiāo é o principal liame da humanidade.

Religião e história hão de prosseguir juntas porque fazem parte da própria natureza divina e humana do homem sôbre a terra. 